\title{
Enterprise Architecture Planning Using TOGAF- ADM at Scoob Telur Company
}

\author{
Perencanaan Arsitektur Enterprise Menggunakan TOGAF-ADM \\ di Perusahaan Scoob Telur
}

Received:

13 July 2019

Revised:

18 November 2019

Accepted:

8 December 2019

\author{
${ }^{1 *}$ Alfredo Gormantara, ${ }^{2}$ Andi Wahju Rahardjo Emanuel \\ ${ }^{1,2}$ Magister Teknik Informatika, Universitas Atma Jaya Yogyakarta \\ ${ }^{1,2}$ Yogyakarta, Indonesia \\ E-mail: ${ }^{1}$ alfredohappy0105@gmail.com, ${ }^{2}$ andi.emanuel@uajy.ac.id \\ *Corresponding Author
}

\begin{abstract}
Scoob Telur is a company that operates in the distribution of eggs in the Province of East Java, especially in the capital city of Surabaya. Unfortunately, business processes ranging from sales, expenses and report generation are still not supported by the use of IS / IT and the absence of strategic information systems planning or mature enterprise architecture. Besides, based on the results of observations and interviews, it was found that there is no information system that can manage financial processes systematically and there are no applications that can help the company's business processes. Based on these, an information system and information technology are needed that can be used to manage the financial process and also control and monitor the company so that it can advance the performance and service of the Scoob Telur company. Enterprise architecture design uses TOGAF ADM, which is a detailed framework used to design, evaluate and build architecture enterprise. The results of this research provide a design that determines business architecture, data architecture, application architecture, technology architecture, and opportunities and solutions and also includes application system design proposals so that it can support business processes as well as making reports that occur on Scoob Telur.
\end{abstract}

Keywords-Enterprise Architecture, TOGAF, ADM, Information System

Abstrak - Scoob telur merupakan sebuah perusahaan yang beroperasi pada bidang pendistribusian telur di Provinsi Jawa Timur terutama di Kota Surabaya. Sayangnya, proses bisnis mulai dari penjualan, pengeluaran dan pembuatan laporan masih belum didukung dengan pemanfaatan SI/TI dan belum adanya pula perencanaan strategis sistem informasi atau arsitektur enterprise yang matang. Selain itu, berdasarkan hasil observasi dan wawancara, ditemukan masalah bahwa belum ada sistem informasi yang dapat mengelola proses keuangan secara sistematis dan tidak adanya aplikasi yang dapat membantu proses bisnis perusahaan. Berdasarkan permasalahan tersebut, dibutuhkan sebuah sistem informasi dan teknologi informasi yang dapat digunakan untuk mengelola proses keuangan serta mengontrol dan memonitoring perusahaan sehingga dapat memajukan kinerja dan layanan dari perusahaan Scoob Telur. Desain arsitektur perusahaan dilakukan menggunakan TOGAF ADM yang merupakan kerangka kerja terperinci untuk merancang, mengevaluasi dan membangun arsitektur perusahaan. Hasil penelilitan ini memberikan desain yang menentukan arsitektur bisnis, arsitektur data, arsitektur aplikasi, arsitektur teknologi dan opportunities and solutions serta juga memberikan usulan rancangan sistem aplikasi sehingga dapat mendukung proses bisnis maupun pembuatan laporan yang terjadi pada Scoob Telur.

Kata Kunci-Enterprise Arsitektur, TOGAF, ADM, Sistem Informasi

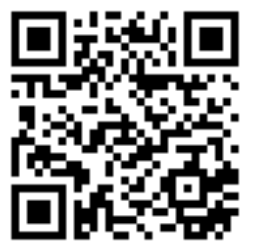




\section{INTRODUCTION}

The development of information systems or technology can improve the performance of an organisation or company. The information system is made into a necessity in a company management organization. Previous information systems have been used in government organizations [1], banking [2], cooperatives [3], hospitals [4], education [5], agriculture [6] and in companies [7]. The company, as an institution in the form of an organization, manages with the aim of providing goods and services for the community with a motive or profit incentive [8]. The development of the need for an information system does not only affect one part of a company that facilitates the entire production, distribution and management of the company. Currently, information technology is part of the organisation to achieve achievement, in other words about information technology that has been obtained as part of the business in a company.

Scoob Telur is a company engaged in the field of goods and services as a distributor of eggs in East Java Province which was approved in 1992. In improving the quality of service, it is necessary to have an information system that can control and support business processes that can be opened from controlling egg stock, selling eggs and even in marketing a company that can facilitate the owner in managing his company. Not all business processes in companies that are supported by SI / IT make the services provided optimally. This is due to the absence of information systems strategic planning, whether the company architecture is applied. Therefore, we need a corporate architecture planning to build information systems or technology on Scoob Telur.

Enterprise architecture (EA) can help in building harmony between IT needs and organisational business so that it helps design infrastructure [9]. Enterprise architecture planning is carried out to provide a proposal or an overview of information system design and technology on Scoob Telur. This is expected to help speed up the process of moving and adopting the use of information systems and technology [10]. Architectural planning is also used to define and clarify the main elements of business, also establishes the business baseline and business targets [11].

The enterprise architecture used in this study is TOGAF (The Open Group Architecture Framework) [12]. TOGAF is a framework for designing enterprise architecture to design, implement, plan and manage enterprise information architectures. More than $80 \%$ of the world's leading companies take the TOGAF certification every year [13]. The core of TOGAF is ADM (Architectural Development Method). TOGAF is used to design information systems strategic planning that uses the leading architecture to map the needs of IS / IT for Scoob Telur. The 
INTENSIF, Vol.4 No.1 February 2020

ISSN: 2580-409X (Print) / 2549-6824 (Online)

DOI: https://doi.org/10.29407/intensif.v4i1.13197

main architectures are business architecture, data architecture, application architecture, and technology architecture [14]. TOGAF has been used in various fields such as architectural design at Bank PT Finnet Indonesia [15], a university [16], a hospital [17] and even government using cloud technology [18].

Based on the above problems, we need an information system and technology that functions to manage the financial processes of Scoob Telur and also control and monitor the company so that it can advance the performance of the Scoob Telur company. Therefore this study uses TOGAF-ADM in designing enterprise architecture on Scoob Telur so that it can solve the problems presented.

\section{RESEARCH METHOD}

This study designed the enterprise architecture on Scoob Telur located in Surabaya, East Java. Figure 1 below explains the stages of the research conducted.

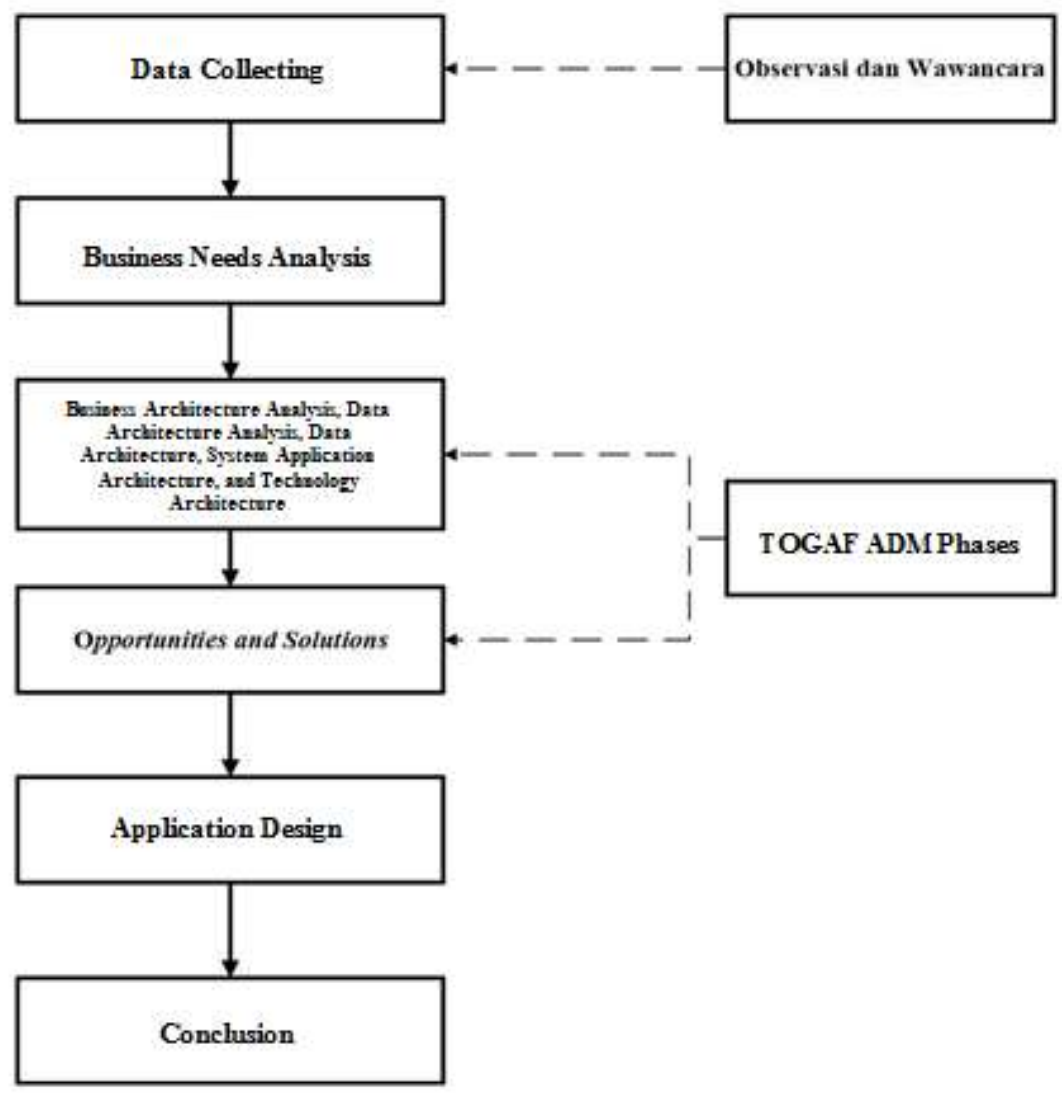

Figure 1. RESEARCH METHODOLOGY

This research method is divided into 6 stages, namely data collection, needs analysis, planning of the leading enterprise architecture using TOGAF-ADM namely business architecture, data architecture, application architecture, technology architecture and opportunities and solutions as well as application design and conclusions. 
In the initial stage, data collection is carried out with the study of literature to find references to previous studies and followed by an observation phase with interviews to the owner and also the Scoob Telur's employees to identify the current system and the problems that often occur. Furthermore, needs analysis is used to analyze business processes that run on Scoob Telur.

Afterwards, it is continued by designing the TOGAF-ADM enterprise architecture, which helps build the architecture framework. The TOGAF-ADM steps taken are the main architecture that is useful for mapping the needs of IS / IT for Egg Scoob. The main architecture is business architecture, data architecture, application architecture, and technology architecture. Then the opportunity and solutions phase is carried out to produce a gap analysis of business architecture that is useful for developing the desired business conditions of the company.

In the application design stage, several designs are made for the application that will be created starting from the sales application page, the stock report application page and the financial statement application page. This design was made to illustrate the application that will be made later. The final stage is the conclusion of the research based on the results obtained.

\section{RESULT AND DISCUSSION}

In designing the enterprise architecture for Scoob Eggs, the section is divided into 3 stages: data collection and needs analysis, ADGA TOGAF phases and application design.

\section{A. Data Collection and Requirement Analysis}

In this study, data collection was done by observation to the Scoob Telur company in Kali Rungkut, Rungkut District, Surabaya City, East Java and conducted interviews with the owner and employees on duty. In addition, observations were also made to the research site to assess the state of IS / IT support directly. From the results of observations and interviews conducted, it is concluded that there are several important points as follows:

1. The business process carried out is still manual and does not use technology at all. The sales process is always carried out by making manual bill (Note) so that errors can occur upon daily sales reports.

2. The method of making and recapitulating the report is done every day when employees want to close the warehouse by entering transaction one by one through a sales bill into Microsoft Excel done by the owner.

3. The payment and instalment process is recorded in a book that is only owned by employees which are making it difficult and lack of functional data integration.

The business processes that are currently running on the Scoob Telur are depicted with the UML diagram in Figure 2 below with 3 main actors, namely customers, employees and company owner. 
INTENSIF, Vol.4 No.1 February 2020

ISSN: 2580-409X (Print) / 2549-6824 (Online)

DOI: https://doi.org/10.29407/intensif.v4i1.13197

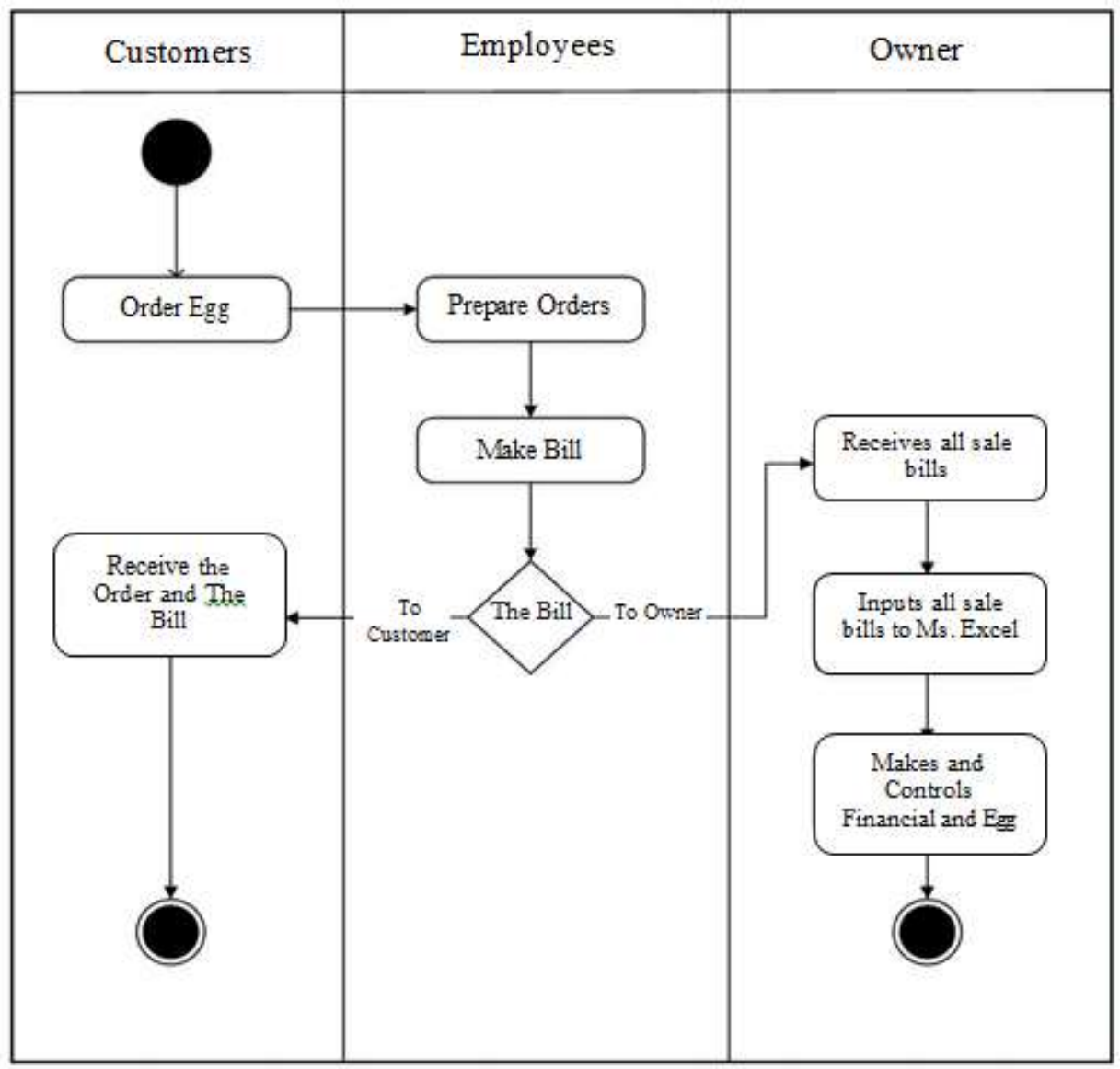

Figure 2. BUSINESS PROCESSES CURRENTLY RUNNING

In Figure 2 above, it can be seen that the business processes currently running on Scoob Eggs focus on tasks for the employee and owner of the company. When the employee makes a memorandum for the buyer, the bill is recapitulated and given to the owner. After that the owner inputs all sales data into Microsoft Excel and makes an egg and financial report on its own so this process makes the task for the owner hard.

\section{B. TOGAF-ADM phases}

This study focuses on several stages on the TOGAF-ADM including business architecture design, data architecture, system application architecture and technology architecture.

1. Business Architecture

In this phase, the business architecture is designed for each activity that has been identified through the interview and observation process depicted in Figure 3 below. The business process that is intended is expected to reduce the workload of employees and company owner so as to optimize business processes. 
INTENSIF, Vol.4 No.1 February 2020

ISSN: 2580-409X (Print) / 2549-6824 (Online)

DOI: https://doi.org/10.29407/intensif.v4i1.13197

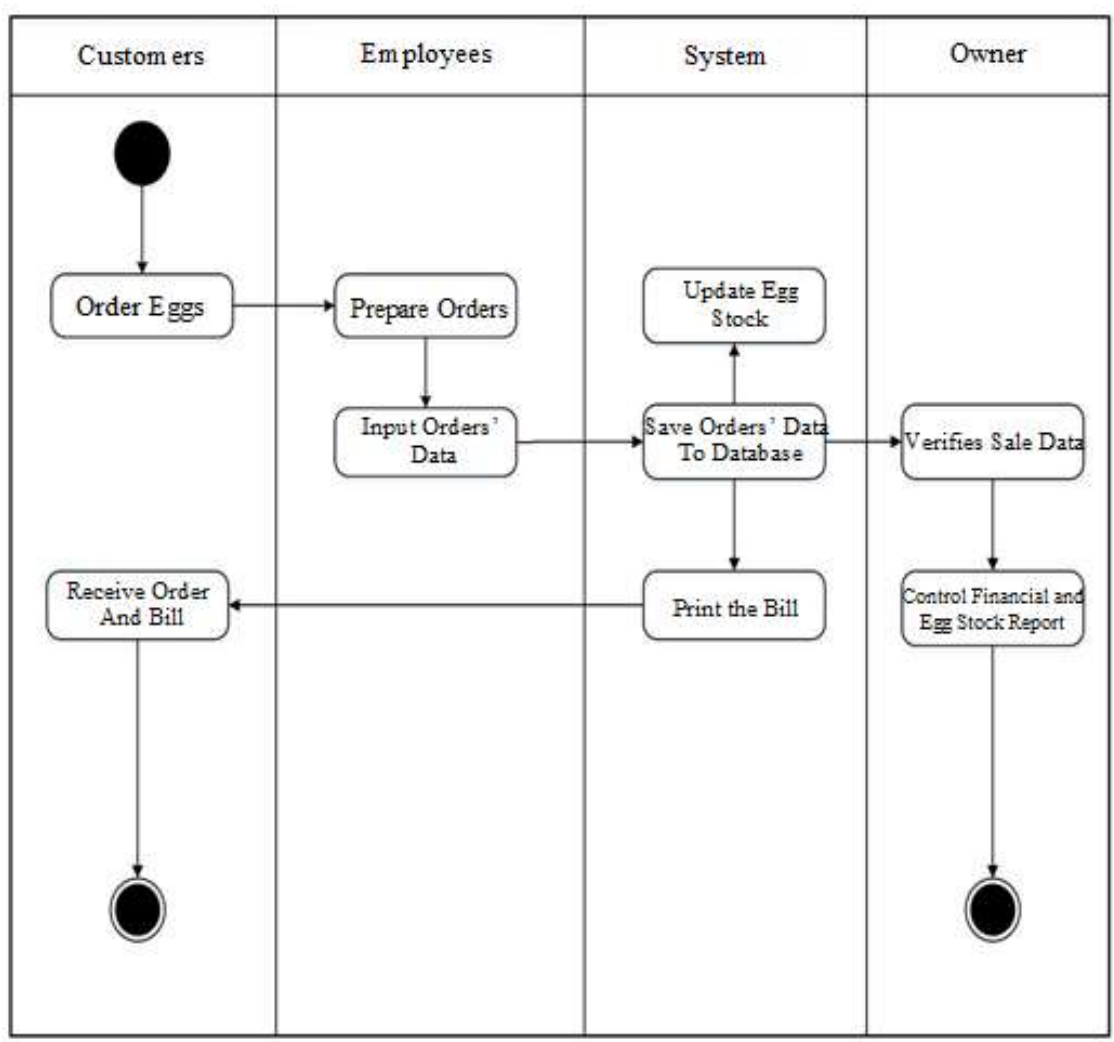

Figure 3. DESIGNED-BUSINESS PROCESS

From Figure 3, it can be seen that a new actor is proposed in the form of a system. The system will take the most crucial role in the proposed business process. Making a memorandum that was previously done manually will be made by the system when the employee inputting the data the buyer's order will automatically print a bill with the printer. Besides, the work of the owner is also reduced which previously had to input sales data one by one to make egg stock and financial reports, then in the business process that is designed will be made by the system so that the owner can monitor the current state of the business. Data that has been inputted by the employee will be integrated directly into the owner so that there is no re-input. The owner will only verify the sales data if there is an input error made by the employee.

2. Data Architecture

This phase explains the data architecture design that huilds the information system that is designed. Data architecture focuses on how data is used in the process of helping to run business functions. Data architecture is created by identifying data components that are used to run applications so that they can help company performance. 
INTENSIF, Vol.4 No.1 February 2020

ISSN: 2580-409X (Print) / 2549-6824 (Online)

DOI: https://doi.org/10.29407/intensif.v4i1.13197

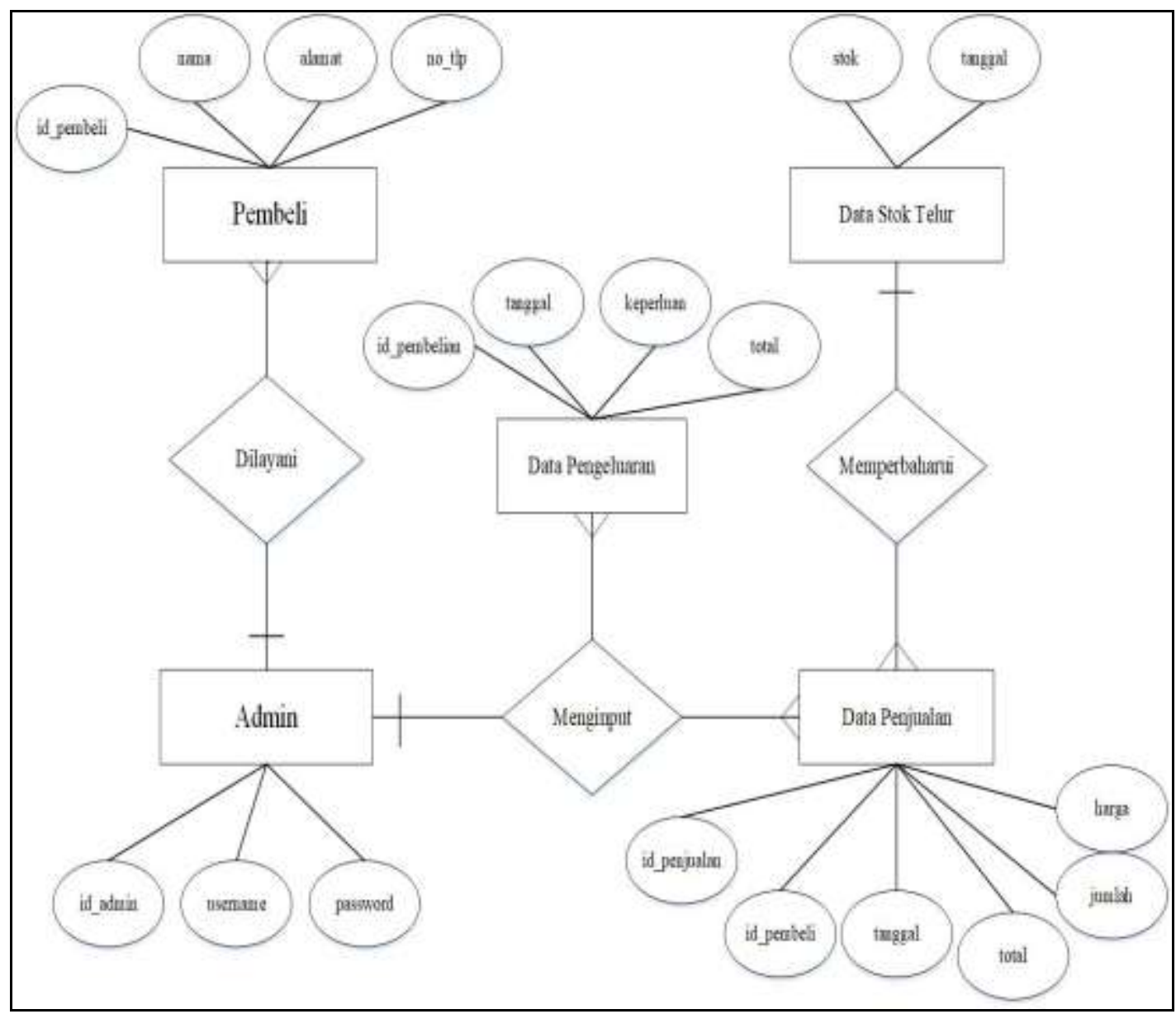

Figure 4. DATA ARCHITECTURE IN THE DIAGRAM

From Figure 4 above shows, there are 5 entities and their attributes that exist in the designed data architecture. Sales data contains egg sales transactions that occur. Expenditure data contains financial data issued by the cashier because for example debt payments, expenses for drivers etc. Egg stock data stores the data in and out of stocks as well as those available in warehouses. Customer data contains customer data such as name, address and telephone number while admin data includes the username and password used when logging into the system.

3. System Application Architecture

Based on the results of interviews and observations, the proposed architecture application is divided into several sections needed to process data and support activities on Egg Scoob. The proposed application is described in Table 1 below. 
INTENSIF, Vol.4 No.1 February 2020

ISSN: 2580-409X (Print) / 2549-6824 (Online)

DOI: https://doi.org/10.29407/intensif.v4i1.13197

Table 1. SySTEM APPLICATION ARCHITECTURE DESIGN

\begin{tabular}{|c|c|}
\hline $\begin{array}{l}\text { APPLICATION } \\
\text { NAME }\end{array}$ & FUNCTION \\
\hline $\begin{array}{l}\text { Sales and Expense } \\
\text { Application }\end{array}$ & $\begin{array}{l}\text { This application serves to record and store all sales } \\
\text { data and expenditure data. }\end{array}$ \\
\hline Stock Application & $\begin{array}{l}\text { This application serves to store data on incoming and } \\
\text { outgoing eggs and update existing egg stock }\end{array}$ \\
\hline $\begin{array}{l}\text { Egg Stock and Financial } \\
\text { Report Application }\end{array}$ & $\begin{array}{l}\text { This application serves to create an egg and financial } \\
\text { report on sales and expenses for the company starting } \\
\text { from day to day, monthly even annually so that the } \\
\text { owner can find out the profit and loss of his company. }\end{array}$ \\
\hline
\end{tabular}

The three proposed system applications, namely sales and expenditure applications, stock applications and financial reporting applications, are the main applications that suit the needs of the company based on the results of interviews and observations.

4. Technology Architecture

Technology Architecture explains and illustrates the mapping of the use of technology, especially hardware and software and even networks, to support system performance. This technology architecture design is designed with a client / server system so that it can be integrated with the database. Technological architecture can be seen in Figure 5 below:

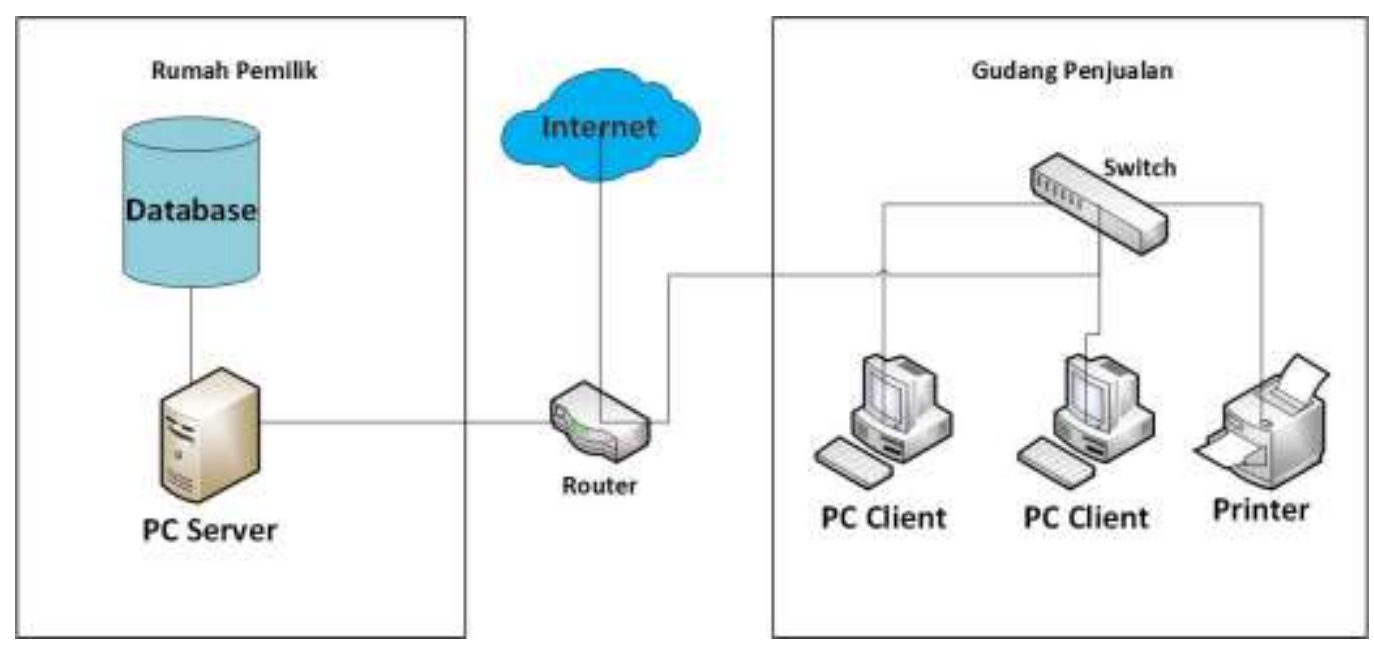

Figure 5. TECHNOLOGY ARCHITECTURE DESIGN

PC Server and PC Client have different locations because the owner's house and egg warehouse are different places. Only one database is used so that data is integrated with one another. As seen in Figure 5, the components needed to design the technology architecture are 1 
INTENSIF, Vol.4 No.1 February 2020

ISSN: 2580-409X (Print) / 2549-6824 (Online)

DOI: https://doi.org/10.29407/intensif.v4i1.13197

PC Server, 2 PC Clients, 1 Router, 1 Printer and 1 Printer. These components are required in order to solve the problems that previously occurred in Egg Scoob.

5. Opportunities and Solutions

This phase is done to make a gap analysis of business architecture, application architecture, data architecture, and technology architecture that has been designed for Scoob Surabaya Eggs. This is done so that the architecture of the IS / IT is made to meet the targets to be achieved before the implementation process is carried out. Following is an example of a gap analysis matrix, which is a gap analysis of business architecture in book management activities, as shown in Figure 6 below.

\begin{tabular}{|c|c|c|c|c|c|c|c|}
\hline Future & 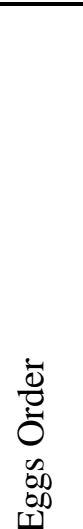 & 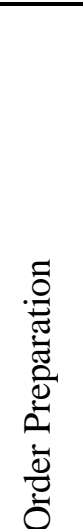 & 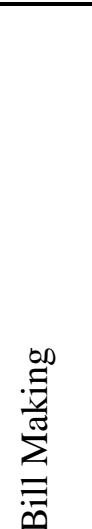 & 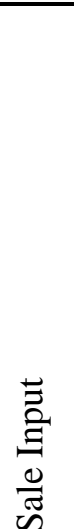 & 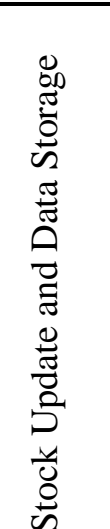 & 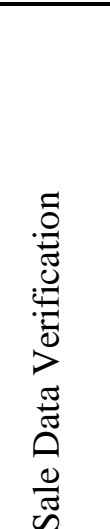 & 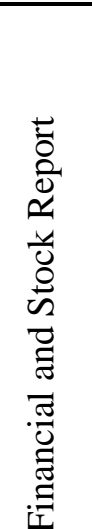 \\
\hline Eggs Order & $\overline{\mathrm{RT}}$ & & & & & & \\
\hline Order Preparation & & RT & & & & & \\
\hline Bill Making & & & $\mathrm{RP}$ & & & & \\
\hline Sale Input & & & & $\mathrm{RP}$ & & & \\
\hline Financial and Stock Report & & & & & & & $\mathrm{RP}$ \\
\hline New & & & & & $A D D$ & $A D D$ & \\
\hline
\end{tabular}

Figure 6. MATRIX ANALISIS GAP ARSITEKTUR BISNIS

$\begin{aligned} \text { Information : RT } & : \text { Retain } \\ \mathrm{RP} & : \text { Replace } \\ \mathrm{RM} & : \text { Remove } \\ A D D & : \text { Additional }\end{aligned}$

Gap analysis is useful to explain the activities contained in existing Surabaya Scoob Eggs to compare current events with proposed architectural targets in business architecture. There are a number of activities that have been retained without making changes, which are egg ordering and order preparation activities - as for the actions of bill making, inputting sales and stock and financial reporting changes are made where there is a role of a system that helps and facilitates the work of employees and owner of these activities. In addition, there are 2 
additional activities carried out on the proposed architecture namely stock updates and data storage and sales data verification. This activity is carried out so that the system can make stock and financial reports from the data in the database while the confirmation of sales data is done so that no input errors are made.

\section{Application Design}

Based on the business analysis process and input from respondents, it can be made a simple application design and easy to understand by the user because the user's understanding of technology is still lacking. Here follows the design of the information system display on the Egg Scoob as follows.

1. Sales Page Views

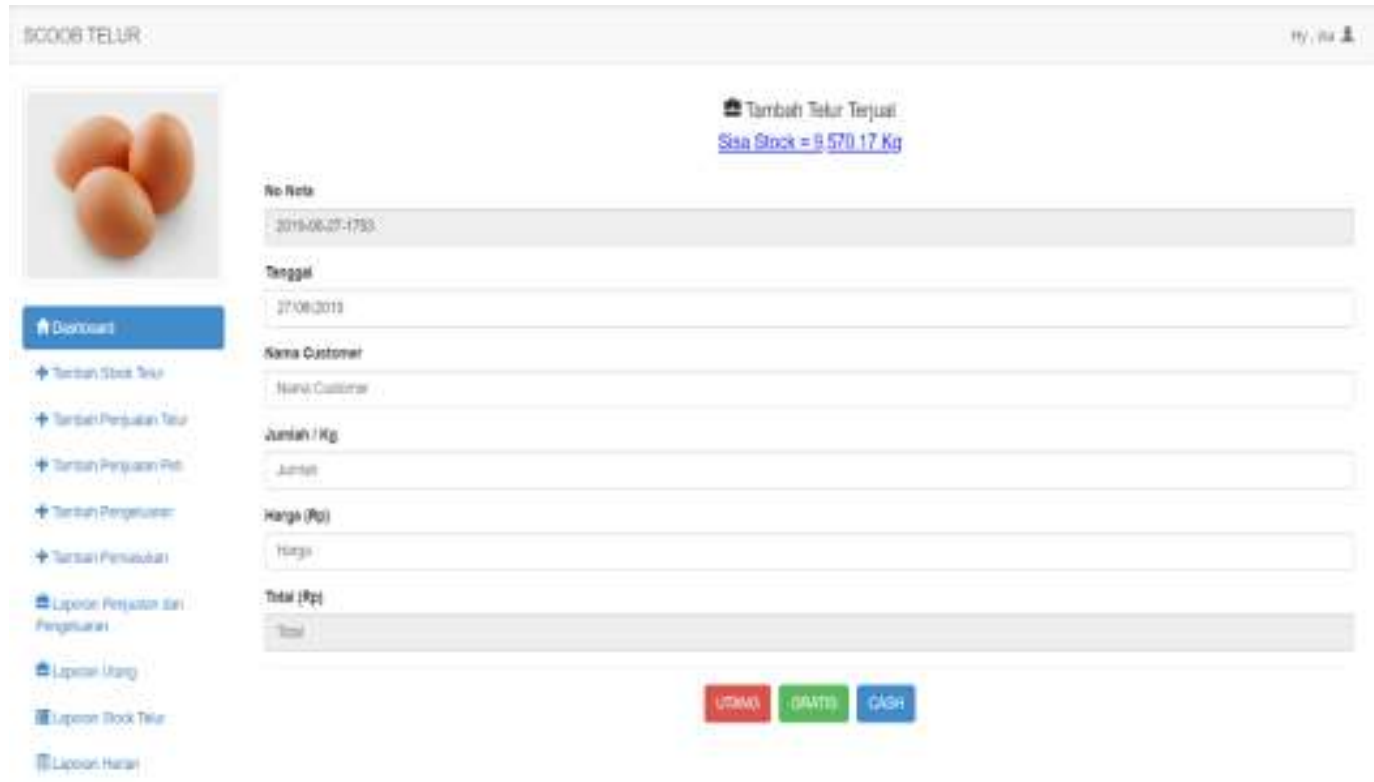

Figure 7. SALES PAGE DisPlay

This page display is a display that is needed by warehouse employees as input to the sales memorandum. This page aims to create a sales memorandum that will be integrated with the memorandum printer so that it will automatically print the bill. The following is the sales page display in Figure 7 below. From the picture above, it can be seen that there are several inputs needed by the system, namely date, name of the customer, amount $(\mathrm{kg})$, the price per $\mathrm{kg}$ and total payment. There is also information about the remaining egg stock in the warehouse which is displayed on this page. 
INTENSIF, Vol.4 No.1 February 2020

ISSN: 2580-409X (Print) / 2549-6824 (Online)

DOI: https://doi.org/10.29407/intensif.v4i1.13197

2. Display Stock Page

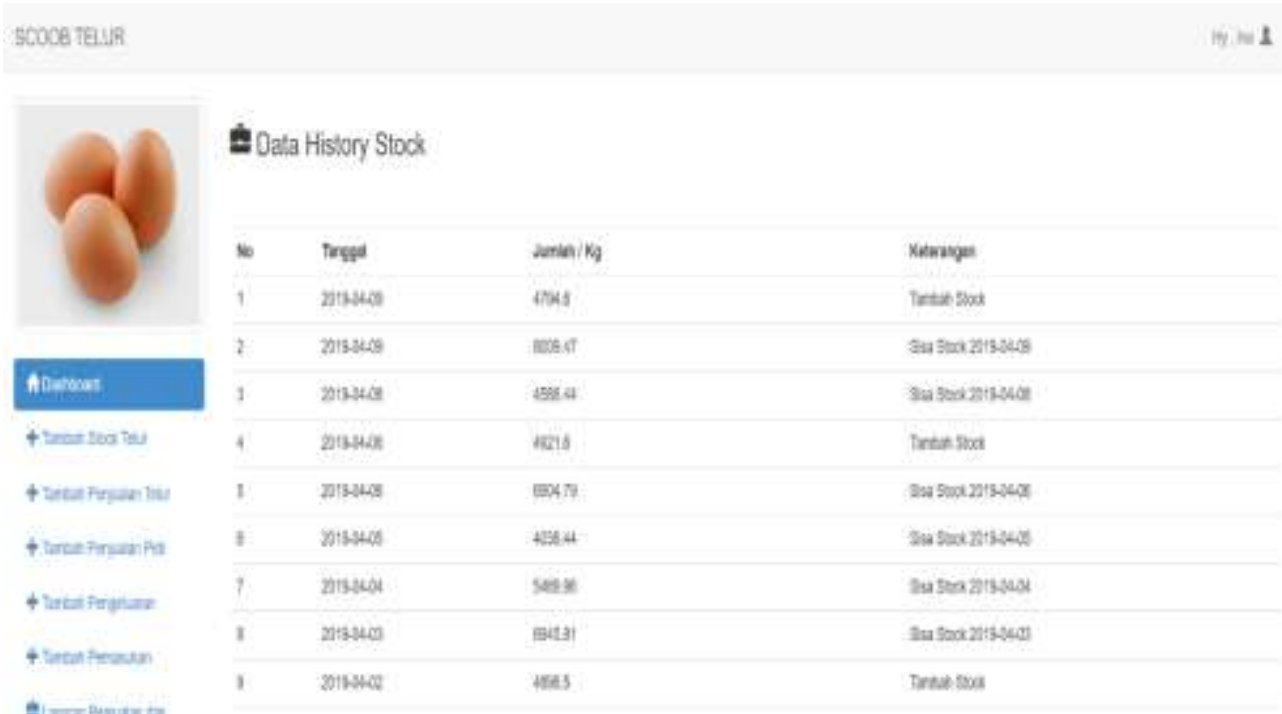

Figure 8. STOCK PAGE DisPlay

This page displays information in the form of changes that occur in the egg stock in the warehouse if there is a reduction or addition. The remaining daily stock will be saved automatically when the warehouse closes. Next is the stock page display in Figure 8 below.

From the picture above it can be seen that the information provided on a daily basis by date, the remaining stock per day is recorded in the remarks column with the contents of the "remaining stock-date".

3. Display of Financial Statement Pages

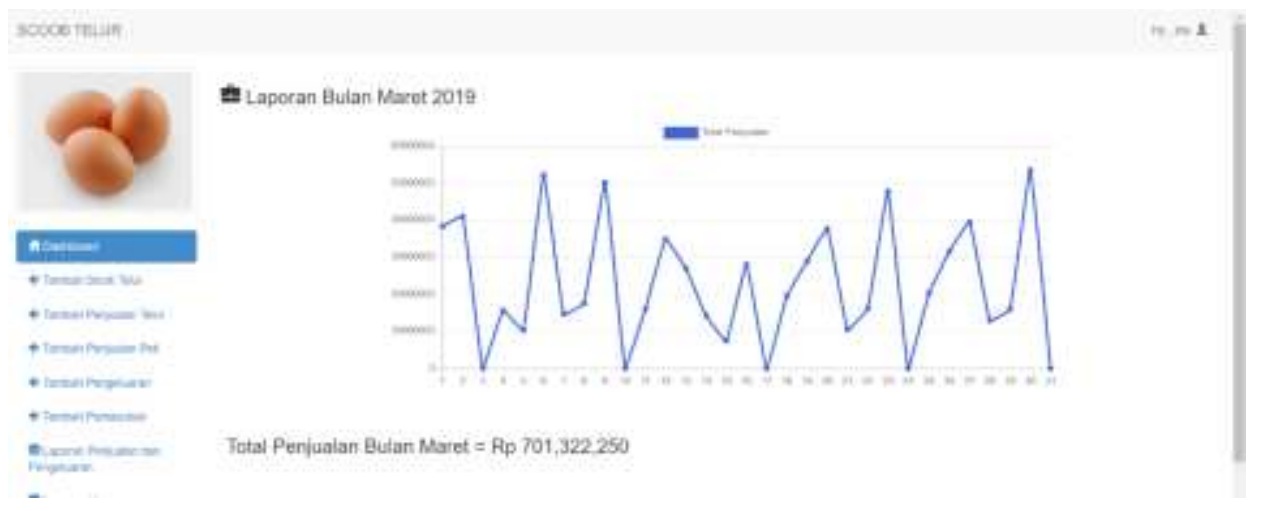

Figure 9. MONTHLY REPORT PAGE DisPlay

This page displays a recapitulation of sales into a financial statement. Total daily sales are made in a chart to show transactions in 1 month. From Figure 9 above, it can be seen that some of the information displayed includes the number of sales per day and total sales of conversations. The appearance is expected to help the owner in understanding the complete sales transactions. In addition, the owner can also print financial reports that have been provided by the system. 
INTENSIF, Vol.4 No.1 February 2020

ISSN: 2580-409X (Print) / 2549-6824 (Online)

DOI: https://doi.org/10.29407/intensif.v4i1.13197

\section{CONCLUSSION}

Based on the results of research conducted on Scoob Telur in Surabaya using TOGAF ADM it can be concluded that the results obtained consist of business architecture design, data architecture, application architecture, network architecture, opportunities and solutions and application design. The application architecture design produces 3 main applications, namely sales and expenditure applications, egg stock applications and egg stock and financial reporting applications. The data architecture consists of 5 entities, namely admin, customer,, sales data, expenditure data and egg stock data. The opportunities and solutions phase produces a gap analysis matrix that helps the future system design process. With this system design is expected to be able to help the process of selling and delivering integrated information for the Scoob Egg company. It is expected that in the future there will be system integration with tools used in the company such as CCTV, scales and others so that it can further advance the company.

\section{REFERENCE}

[1] A. K. Darmawan and A. Dwiharto, "Pengukuran Capability Level Kualitas Layanan EGovernment Kabupaten Pamekasan Menggunakan Framework COBIT 5.0," INTENSIF J. Ilm. Penelitian. dan Penerapan Teknol. Sist. Inf., vol. 3, no. 2, p. 93, 2019.

[2] A. F. Syarif, P. N. Basuki, and A. F. Wijaya, "Analisis Kinerja Sistem Informasi pada PT. Bank Central Asia Menggunakan IT Balanced Scorecard,” J. Sist. Inf., vol. 7, no. 1, pp. 1491-1502, 2018.

[3] solichin nusa putra rina trisminingsih, "Perancangan Arsitektur Enterprise untuk Koperasi Pertanian Menggunakan Enterprise,” J. Sist. Inf., vol. 9, no. 1, pp. 1138-1148, 2014.

[4] L. S. Helling, E. Wahyudi, and H. Hasanudin, "Siremis: Sistem Informasi Rekam Medis Puskesmas Kecamatan Matraman Jakarta," INTENSIF J. Ilm. Penelit. dan Penerapan Teknol. Sist. Inf., vol. 3, no. 2, p. 116, 2019.

[5] R. Pamungkas, "Perancangan Sistem Informasi Pembayaran Administrasi SMK Negeri 1 Jiwan," Intensif, vol. 1, no. 2, p. 129, 2018.

[6] R. Delima, H. B. Santoso, and J. Purwadi, "Architecture vision for Indonesian Integrated Agriculture Information Systems using TOGAF framework," 2016 Int. Conf. Informatics Comput. ICIC 2016, no. Icic, pp. 66-71, 2017.

[7] N. A. Susanti, R. R. Saeduddin, and A. Sadat, "Perancangan Enterprise Architecture Pada Fungsi Finance Di PT Albasia Nusa Karya Kabupaten Garut Menggunakan Framework TOGAF ADM," Insight, vol. 1, no. Agustus, pp. 228-233, 2018.

[8] "Pengertian Perusahaan: Unsur-Unsur , Jenis , dan Contoh Perusahaan Pengertian Perusahaan Secara Umum Pengertian Perusahaan Menurut Para Ahli," 2019. [Online]. Available: $\quad$ https://www.maxmanroe.com/vid/bisnis/pengertian-perusahaan.html. [Accessed: 20-Jun-2019].

[9] C. M. Firmansyah and Y. Bandung, "Designing an enterprise architecture government organization based on TOGAF ADM and SONA," 2016 Int. Conf. Inf. Technol. Syst. Innov. ICITSI 2016 - Proc., 2017.

[10] B. Rianto, L. Lidya, and G. W. Nurcahyo, "Pemodelan Arsitektur Enterprise Menggunakan Metode Togaf ADM Studi Kasus Dinas Kesehatan Kabupaten Indragiri Hilir," J. Komput. Terap., vol. 2, no. 1, pp. 55-68, 2016. 
INTENSIF, Vol.4 No.1 February 2020

ISSN: 2580-409X (Print) / 2549-6824 (Online)

DOI: https://doi.org/10.29407/intensif.v4i1.13197

[11] A. Cabrera, M. Abad, D. Jaramillo, J. Gómez, and J. C. Verdum, "Definition and implementation of the enterprise business layer through a business reference model, using the architecture development method ADM-TOGAF," Adv. Intell. Syst. Comput., vol. 405, pp. 111-121, 2016.

[12] B. D. Rouhani, M. Naz, F. Nikpay, M. K. Najafabadi, and P. Nikfard, "A Framework for Evaluation of Enterprise Architecture Implementation Methodologies," Int. J. Soc. Behav. Educ. Econ. Bus. Ind. Eng., vol. 9, no. 1, pp. 1-6, 2015.

[13] T. Open and G. Architecture, "Apa Itu TOGAF? - Framework TOGAF," 2019. [Online]. Available: https://itgid.org/framework-togaf/. [Accessed: 20-Jun-2019].

[14] N. Rizky, Fitroh, and A. F. Firmansyah, "PERENCANAAN ARSITEKTUR ENTERPRISE MENGGUNAKAN TOGAF ADM VERSI 9 (Studi Kasus: Bimbel Salemba Group),” J. Sist. Inf., vol. 10, no. 1, pp. 11-20, 2017.

[15] F. S. Pratama, A. F. Santoso, and R. Hanafi, "Analisis Dan Perancangan Technology Architecture Dengan Framework Togaf Adm Studi Kasus Sistem Payment Point Online Bank Pt Finnet Indonesia," eProceedings Eng., vol. 2, no. 2, pp. 5094-5102, 2015.

[16] R. Setiawan, "Perancangan Arsitektur Enterprise Untuk Perguruan Tinggi Swasta Menggunakan TOGAF ADM," J. Algoritm. STT Garut, vol. 12, no. 1, p. 14, 2015.

[17] C. Vangoslava, Zulfiandri, and M. N. Gunawan, "PERENCANAAN ARSITEKTUR ENTERPRISE DENGAN METODE TOGAF VERSI 9 (STUDI KASUS: RUMAH SAKIT UMUM KOTA TANGERANG SELATAN," J. Sist. Inf., vol. 10, no. 1, pp. 1-9, 2017.

[18] B. Alghamdi, L. E. Potter, and S. Drew, "Desinge and implementation of government cloud computing requirements: TOGAF," Proceeding 2017 11th Int. Conf. Telecommun. Syst. Serv. Appl. TSSA 2017, vol. 2018-Janua, pp. 1-6, 2018. 